\title{
World Orders and the Politics of Exclusion: from Westphalia to Today
}

\author{
Lascurettes, Kyle M. Orders of Exclusion: \\ The Strategic Sources of Order in International Relations. \\ New York: Oxford University Press, 2020.
}

\begin{abstract}
Andrei P. Tsygankov, San Francisco State University, San Francisco, USA
\end{abstract}
\section{Correspondence: andrei@sfsu.edu}

The decline of the contemporary world order and the rise of non-Western powers are among the most closely watched international developments by scholars across the globe. Some scholars point to the rise of China's material capabilities, which are in many areas on a par with those of the United States, particularly following the COVID-19 pandemic. Others maintain that the overall power of the United States will remain unmatched for the foreseeable future, and that the presidency of J. Biden is about to reinvigorate America's primacy in the world. Still others point to growing trends of prolonged instability in the international system, as well as within domestic societies.

Most analysts agree, however, that the contemporary U.S.-centric international order is experiencing serious problems. This begs at least two scholarly questions. First: Is the current order designed to be sufficiently inclusive for its major participants? Second: What is behind specific decisions regarding the design of the international order? In international relations theory, realists and liberals provide different answers to these questions. For example, American liberals such as J. Ikenberry and J. Nye point to the relative openness of the U.S.-centered order and the ability to take the positions of others into account in the interests of preserving global security, prosperity, and the protection of human rights. These scholars view the international order as being based on liberal ideas championed by the United States. Realists including J. Mearsheimer, S. Walt and others disagree, claiming that the American order is self-serving and is increasingly unable to integrate China, Russia, and some other powers. To them, a stable world order results from the correct assessment of the balance of power in the international system and should not be based on the ideas of one of the system's actors. 
The book by K. Lascurettes contributes to this debate by offering a new synthesis of scholarly literature and a review of historical cases since the Peace of Westphalia. K. Lascurettes' theory is that of a self-confessed realist, albeit one who believes in gaining important insights from liberal IR theorists. In particular, he complements his analysis of threats and material capabilities with ideas held by prominent international actors. He builds, among other things, on the work of J. Legro, a pioneer of strategic ideas, author of an important work on the subject, ${ }^{1}$ and K. Lascurettes' PhD adviser at the University of Virginia.

Below, I review K. Lascurettes' arguments, cases, and assessment of U.S.-China competition in shaping the international order. I argue that the book greatly contributes to our knowledge of how international orders are formed by drawing attention to state prioritization of security threats, rather than interests of common security and prosperity. I also argue that the author's strategy with respect to framing the dependent variable and its explanation raises some methodological issues. K. Lascurettes' research approach constrains his choices and closes some opportunities for analyzing international orders. Overall, his analysis is important, yet it remains incomplete and potentially misleading, and thus calls for additional research of the issue.

The book's central argument is that state preferences with respect to world order can be described as favoring or not favoring the inclusion of other states as active members of a newly emerging international system. These preferences are driven by the perception of threats presented by other states, both geopolitical and ideational. If such a threat is present, then the choice will be in favor of excluding the state that poses the threat from the system by designing rules and principles that severely constrain that state's membership in the system. According to K. Lascurettes, this exclusion is accomplished through three distinct strategies (pp. 40-41). First, dominant states can make others more aware of their commonalities with respect to the potentially serious threat ("commonalities for contrast"). Second, such states can set territorial and rhetorical boundaries by invoking particular ideas and preventing the expansion of the threat ("triggering tripwires"). Third, they can strategically invoke principles to undermine the threatening state's "ontological security" ("severing social power"). The latter strategy was applied by the United States to M. Gorbachev for securing his acquiescence to the reunified Germany joining NATO. In this case, M. Gorbachev's own statements about self-determination and "freedom of choice" were used against him.

The treatment of M. Gorbachev at the end of the Cold War is, therefore, an example of the exclusion of the Soviet Union by Western powers despite all the reforms the latter had introduced. K. Lascurettes' assessment that the West did indeed seek to exclude, rather than include M. Gorbachev's ideas and propose a new world order is an important acknowledgment of what has long been denied by Western liberal scholars of the Cold War.

The main theoretical target of the book is liberalism and liberal reasoning about world order. In particular, K. Lascurettes engages with three types of liberal reasoning that explain why important world orders such as the one formed after the Cold War are sufficiently inclusive: international institutionalism, domestic liberalism, and international learning. The three arguments are distinct, yet each favors the theory 
that the world order was designed to incorporate diverse international participants and teach them new global norms of behavior.

$\mathrm{K}$. Lascurettes presents a realist argument, yet is critical of neorealism. He views neorealist approaches as overly materialistic and unnecessarily dismissive of ideas, idea-based threats, and even the need for the establishment of an international order. The author sees his argument as consistent with classical realism, which is open to an analysis of the ideas and domestic conditions of states. However, he is also critical of classical realists for their lack of a theory of state preferences and insists that states have rationally defined preferences. Here, he remains on the neorealist ground. Neorealists commonly argue that states are rational in their behavior and that such rational behavior results from pressures/opportunities presented by the international system. Adding ideas does not change the neorealist reasoning, so long as the international system remains the ultimate source of state actions. Even the relatively new realist approach - the so-called neo-classical realism - is no different on this account. Alternatively, classical realism recognizes that state preferences and rationality cannot be fully determined by the international system and are partly defined by domestic culture. R. Gilpin, who is cited in the book, as well as E.H. Carr, H. Morgenthau, G. Kennan, and other classical realists were "indeterminate" with respect to state preferences by recognizing the prominence of domestic politics and national beliefs in shaping the choices of leaders.

Having laid out his research design and theory in chapters 2 and 3, K. Lascurettes tackles some historical cases. Chapters 4 and 5 review European developments from the Peace of Westphalia in the 17th century to the Congress of Vienna in the 19th century. Chapters 6, 7, and 8 analyze cases from the point of view of the United States following the end of World War I, World War II, and the Cold War, respectively.

In all these cases, the author finds evidence of his theory of exclusion. Following the Peace of Westphalia, the victors of the Thirty Years' War sought to exclude those who had claims to universal authority in Europe - the Habsburg Empire and the Catholic Church. In particular, France and Sweden limited claims to rival authority by insisting on new territorial arrangements and undermining imperial and religious "social power" (p. 63). Using these strategies, Westphalia prevented potential conflicts in Europe throughout the 18th century following the War of the Spanish Succession (1702-1713) waged by Great Britain and its allies. Great Britain emerged as the dominant state after the Peace of Utrecht (1712-1713) and the 1763 Treaty of Paris.

The Congress of Vienna of 1813-1814, despite "an unprecedented amount of elitelevel contact through frequent meetings" and "remarkable cooperation" (p. 95), also resulted in the exclusion of important actors. The main object of exclusion in this case was the threat posed by Revolutionary France. While perceived differently by different actors, all of them agreed that France was to be "excluded." Even the British, who did not care about the autocracy principle advocated by Russia and Austria, argued for "protection and security" of different Great Powers against the potential revisionism of Napoleon.

The Wilsonian world order project following World War I, of course, did not include Germany. The new international system sought to control Germany's ambitions, including through the previously not exploited principle of self-determination and "orderly democratic institutions" (p. 138). The victors of the war were afraid of 
Germany's geopolitical ambitions and its absolutist principles of domestic order. In K. Lascurettes' analysis, the founders of the Versailles Treaty were even more fearful of Bolshevism and the challenge that the rise of new Soviet Russia presented for new world order.

Similarly, K. Lascurettes argues that the world order that formed following World War II was largely the result of a fear of the USSR and was therefore similar in origins to the Cold War. In his assessment, both F. Roosevelt and W. Churchill were far more concerned about Stalin and the Soviet Union than they were about Germany. They viewed the post-war period and the relative weakness and poverty of the Soviet Union as an important opportunity to shape the international order according to their principles and preferences. These principles had already been laid out in the Atlantic Charter of 1941 and F. Roosevelt's "four freedoms": "of speech, of religion, from (economic) want, and from fear (of war)." (p. 167). The Western leaders were scared of fascist and communist ideologies, as well as Soviet power.

Finally, the post-Cold War order too emerged from Western desires to exclude or limit the power of the Soviet Union, as the above-cited references to the treatment of Gorbachev demonstrate.

In order to present the range of outcomes, K. Lascurettes analyzes not only cases of changing world orders, but also those of continuity. Consistent with his theory, he argues that, in those cases, there were no major threats to world order-defining states, so there was no need to push for a change of existing international norms and principles.

The author concludes by assessing his theoretical framework as superior to alternative explanations. He also offers an analysis of the future world order in relation to China and its behavior in the international system. K. Lascurettes is pessimistic about the possibility of including China in a U.S.-centered world order, as China's ideas and geopolitical power represent a threat to such an order. However, he recommends one last try in the near future as a preamble to launching the strategy of exclusion in the long term.

Overall, the book presents an important intervention in our thinking about world order. In American academic circles, it will add to the body of work challenging the dominant liberal narrative by identifying what liberals often fail to acknowledge, namely that all state choices with respect to those actors perceived as a threat are of an exclusionary nature. Liberal states are only prepared to include countries that are willing to operate on strategic, political, and value terms designed by liberals in their international order. In the Russian context, the book will challenge the narrative of the post-American world order with its expectations of the continued rise of non-Western powers such as China and Russia. According to K. Lascurettes, such a world order is not realistic if it is based on excluding the United States.

One problem with $\mathrm{K}$. Lascurettes' argument is that presenting state choices of the international order as a dichotomy of exclusion versus inclusion is overly simplistic. In practice, state choices are more complex and vary in the degree of their inclusion in a given system. For example, the Vienna system integrated the defeated France, whereas the Versailles system following World War I fully excluded Germany by imposing reparations and constraining German foreign policy. Russia after the Cold War has fallen somewhere in between. The West did not force Russia to pay reparations and even extended its membership in the G7. 
Yet the West has nevertheless sought to control Russian foreign policy, particularly in Eurasia, and never considered including Russia in NATO and the European Union.

The range of possible actions with respect to preferred world order is, therefore, broader than K. Lascurettes' study argues, and this calls for greater complexity in theory-building. K. Lascurettes' theory of rational state behavior is incomplete and unable to account for the divergence of outcomes in state behavior. As Kalevi Holsti showed in his magisterial study of international orders, ${ }^{1}$ policymakers are never guided by rationality, and so neither should scholars. Instead, scholars should concentrate on studying individual state beliefs and positions. These beliefs and positions should not be taken for granted and viewed as predominantly formed by the international system. A more complex theory should aim to integrate threats at the level of the international system with national institutional and perceptual variables. There is a great need for dialogue between realism, on the one hand, and liberalism and constructivism, on the other. Addressing alternative liberal explanations by merely demonstrating their deficiencies, as K. Lascurettes does, is helpful yet insufficient. A greater challenge is to integrate liberal and constructivist variables by demonstrating not only their relative weaknesses, but also their relative strengths and the conditions under which they must be a part of scholarly analysis.

This critique does not invalidate the author's contribution. Although K. Lascurettes' approach is incomplete in accounting for the wealth of rich historical evidence, the author should be commended for his new theoretical synthesis and the fact that he covered a huge range of large historical material. Both scholars and students will benefit from reading this important book, which could be used in both graduate and upper-division undergraduate courses.

1 Holsti 1991.

СПИСОК ЛИТЕРАTУРЫ / REFERENCES

Legro, Jeffrey. Rethinking the World: Great Powers Strategies and International Order. Ithaca, NY: Cornell University Press, 2007.
Holsti, Kalevi J. Peace and War: Armed Conflicts and International Order 1658-1989. Cambridge: Cambridge. University Press, 1991. 


\section{Author}

Andrei P. Tsygankov,

Professor of International Relations and Political Science at San Francisco State University, 1600 Holloway Ave, San Francisco, CA 94132.

e-mail: andrei@sfsu.edu

\section{Additional information}

Received: March 23, 2021. Accepted: April 23, 2021.

\section{Disclosure statement}

No potential conflict of interest was declared by the author.

\section{For citation}

Tsygankov, Andrei P. "World Orders and the Politics of Exclusion:

from Westphalia to Today." Journal of International Analytics 12, no. 1 (2021): 176-182. https://doi.org/10.46272/2587-8476-2021-12-1-176-182 


\section{Сведения об авторе}

Андрей Павлович Цыганков,

профессор международных отношений и политических наук

Калифорнийского Университета Сан-Франциско, Сан-Франциско, США, 94143.

e-mail: andrei@sfsu.edu

\section{Дополнительная информация}

Поступила в редакцию: 23 марта 2021. Принята к публикации: 23 апреля 2021.

\section{Конфликт интересов}

Автор заявляет об отсутствии конфликта интересов.

\section{Цитирование}

Цыганков, А.П. Мировые порядки и политика исключения:

от Вестфалии до наших дней // Международная аналитика. - 2021. - Том 12 (1). - С. 176-182. https://doi.org/10.46272/2587-8476-2021-12-1-176-182 